\title{
GEOPROCESSING APPLIED TO RISK ASSESSMENT OF FOREST FIRES IN THE MUNICIPALITY OF BODOQUENA, MATO GROSSO DO SUL ${ }^{1}$
}

\author{
Vitor Matheus Bacani ${ }^{2 *}$ \\ ${ }^{1}$ Received on 24.03.2015 accepted for publication on 25.10.2016 \\ ${ }^{2}$ Universidade Federal de Mato Grosso do Sul, Campus de Três Lagoas, Três Lagoas, MS - Brasil. E-mail: <bacani_ufms@yahoo.com.br>. \\ *Corresponding author.
}

\begin{abstract}
Forest fires are a permanent threat in urban-forest interface areas and cause considerable environmental damage, especially in protected areas. An efficient way to assist decision-making to prevent an increase in forest fires is risk assessment using geographical information systems (GIS). The objective of this study was to evaluate the risk of forest fires in the municipality of Bodoquena, Mato Grosso do Sul, Brazil, using remote sensing data and spatial analysis techniques implemented in a GIS. The procedures of the methodology are based on spatial analysis techniques to prepare maps of the likelihood of fire based on calculations of the Euclidean distance, the Kernel statistical method and fuzzy transformation and to combine these maps via the increasing diffuse overlay method. The results showed a high risk of forest fires on the margins of the urban area, rural settlements and main roads that cross the municipality, as well as the surrounding areas. It is concluded that the municipality of Bodoquena has a high risk of forest fires in areas with high biodiversity, especially the areas surrounding the Serra da Bodoquena National Park and Mato Grosso do Sul Pantanal.
\end{abstract}

Keywords: GIS, Serra da Bodoquena, Conservation Unit.

\section{GEOPROCESSAMENTO APLICADO À AVALIAÇÃO DE RISCO DE INCÊNDIO FLORESTAL NO MUNICÍPIO DE BODOQUENA, MATO GROSSO DO SUL}

\begin{abstract}
RESUMO - Incêndios florestais constituem uma ameaça permanente em áreas com uma interface urbanoflorestal e provocam considerável dano ambiental, sobretudo em unidades de conservação. Um modo eficiente de auxiliar a tomada de decisão para evitar a intensificação de incêndios florestais é através da avaliação de risco por meio de Sistema de Informação Geográfica (SIG). O objetivo deste trabalho foi avaliar o risco de incêndio florestal do município de Bodoquena-MS, por meio de dados de sensoriamento remoto e técnicas de análise espacial implementadas em um SIG. Os procedimentos metodológicos fundamentaram-se em técnicas de análise espacial para elaboração de cartas de probabilidade de ocorrência de incêndio com base no cálculo de distância euclidiana, no método estatístico de Kernel, na transformação fuzzy e combinação pelo método de sobreposição difusa crescente. Os resultados mostraram alto risco de incêndio florestal às margens da área urbana, assentamentos rurais e das principais estradas que cortam o municipio, além do entorno de unidades de conservação. Conclui-se que o município de Bodoquena apresenta alto risco de incêndio florestal em áreas de elevada riqueza de biodiversidade, com destaque para o entono do Parque Nacional da Serra da Bodoquena e o Pantanal sul-mato-grossense.
\end{abstract}

Palavras-chave: SIG; Serra da Bodoquena; Unidade de Conservação. 


\section{INTRODUCTION}

\subsection{General Aspects}

Forest fires are a constant threat in areas with an urban-forest interface (SOTO, 2012). They can cause considerable environmental damage, especially in protected areas, such as biodiversity loss, soil erosion, emission of gases into the atmosphere that intensify the greenhouse effect and decreased local air quality (SILVA et al., 2003; SILVEIRA et al., 2008).

An efficient way to assist decision-making to prevent an increase in forest fires is through risk assessment by classification of the type of road infrastructure and environmental variables in a database using a geographic information system (GIS) (BURROUGH, 1989; VETTORAZZI; FERRAZ, 1998). These assessments can be applied to private areas, conservation units and even at the municipal level as long as the local variables that influence the risk of fire are properly considered (RIBEIRO et al., 2008).

By mapping the areas of risk, it is possible to control and minimize the frequency of forest fires, preventing environmental damage. Forest fire risk areas are places where a fire is likely to start and areas where it can easily spread to other areas. An accurate assessment of the forest fire problem areas and decisions about solutions is feasible only when a map of fire risk zones is available (JAISWAL et al., 2002).

According to Alves; Nóbrega (2011), even with the adoption of forest fire monitoring and prevention measures by agencies such as the Brazilian National Institute of Space Research (Instituto Nacional de Pesquisas Espaciais - INPE) and satellite imagery and surveillance actions performed by the Brazilian Institute of Environment and Renewable Natural Resources (Instituto Brasileiro do Meio Ambiente e dos Recursos Naturais Renováveis - IBAMA), among other federal, state and municipal agencies, forest fires are still considered to be an extremely serious problem in Brazil.

In this context, the municipality of Bodoquena stands out because it is in the transition region of the Cerrado-Pantanal biomes (IBGE, 2004) and has one of the largest continuous Atlantic Forest reserves in the state of Mato Grosso do Sul (Serra da Bodoquena National Park), which is located in the overlapping area of two biosphere reserves recognized by the United Nations Educational, Scientific and Cultural Organization
(UNESCO): the Pantanal and Atlantic Forest biospheres (SALZO, 2013). Although it is a municipality with rich biodiversity, especially in the forest reserves, human settlement has intensified, and there are still no maps indicating areas of higher probability of the occurrence of a forest fire.

The objective of this study was to evaluate the risk of forest fires in the municipality of Bodoquena using remote sensing data and spatial analysis techniques implemented in a GIS.

\subsection{Study area}

The municipality of Bodoquena is located in the western part of the state of Mato Grosso do Sul with a topography of 99 to 821 meters in altitude (Figure 1) and an area of $2,507.319 \mathrm{~km}^{2}$. It had an estimated population of 7,938 inhabitants in 2014 (IBGE, 2015).

Bodoquena has outstanding tourist potential, especially eco-tourism, and there is agriculture in the transition between the Serra da Bodoquena karst system
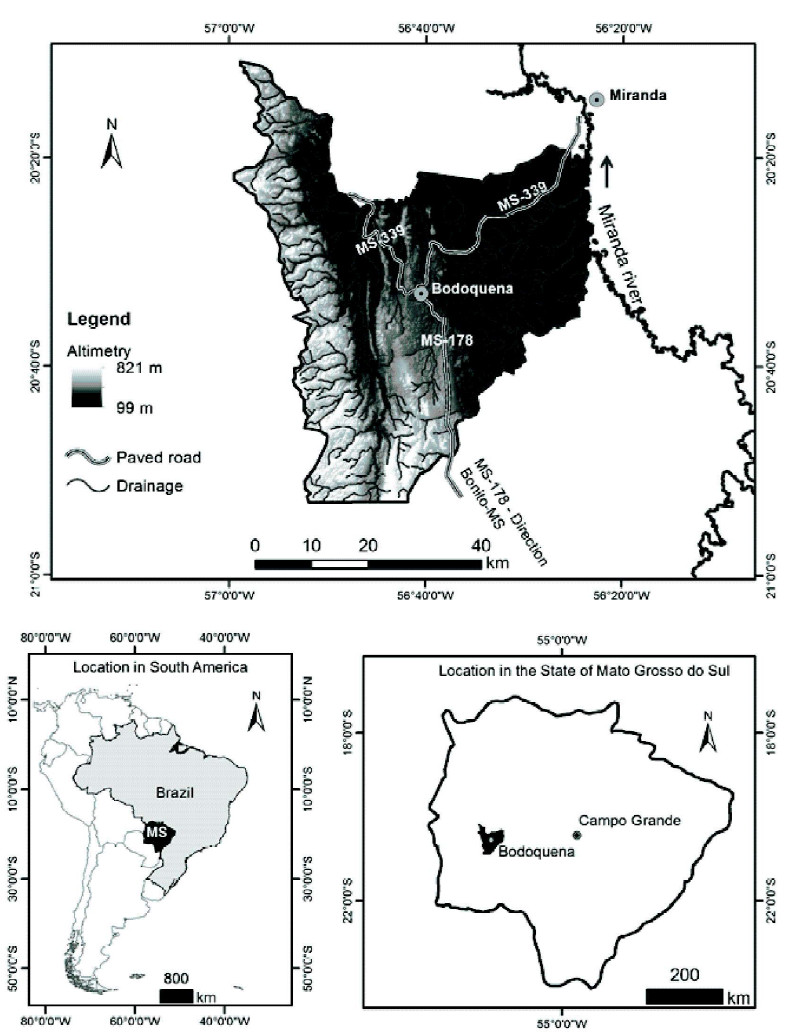

Source: IBGE (2013). valeniano (2008). Projection: Geographic. Datum SIRGAS 2000.

Figure 1 - Location of the study area.

Figura 1 - Localização da área de estudo. 
(ALMEIDA, 1965) and the Paraguay River depression (BRAZIL, 1982). Therefore, it is a water and sediment source area that supplies the Pantanal plains, located in the Miranda River basin, and it is a member of the Upper Paraguay River basin.

The geological framework is composed of rocks of the Cuiabá Group, Cerradinho Formation, Bocaina Formation and Pantanal Formation (CPRM, 2006). Geomorphologically, it is included in the morphostructural unit of the Paraná sedimentary basin, modeled by the morphosculptures of the Bodoquena Plateau and the Paraguay River Depression. The predominant landforms are pediplain erosion surfaces, created by pediplanation processes, which cut Precambrian lithologies of the Cuiabá and Corumbá groups and Devonian and Permo-Carboniferous rocks of the Paraná Sedimentary Basin. Tabular forms with flattened top reliefs with different orders of magnitude and drainage depths also occur and are separated by flat bottomed valleys. To a lesser extent, there are convex landforms of different orders of magnitude and drainage depths separated by flat bottomed and/or "V" shaped valleys (BRASIL, 1982; BRASIL, 1997).

The predominant soils are red-yellow Argisols, Regolithic Neosols, Rhendzic Chernosols, Argilluvic Chernosols, Natric Planosols, Vertisols and Humic Gleysols (BRASIL, 1997; EMBRAPA, 2013).

The regional climate is classified as tropical humid with the following characteristics: effective humidity index annual values ranging from 40 to $60 \%$; the annual rainfall is the highest in the state of Mato Grosso do Sul, ranging from 1,750 to $2,000 \mathrm{~mm}$ annually; the annual water surplus is 1,200 to $1,400 \mathrm{~mm}$ for 7 to 8 months and the water deficit 200 to $350 \mathrm{~mm}$ for 3 months; and the annual mean temperature is $23^{\circ} \mathrm{C}$, among the lowest in the state (MS, 1990).

The current land use is dominated by agriculture that consists of planted pastures and cultivation of crops in rural settlement areas (BRASIL, 1982; SILVA et al., 2011). In Serra da Bodoquena, there is a discontinuous extension of the Inland Atlantic forest, the Semideciduous Seasonal Forest (RAMOS et al., 2008). In adjacent areas, the natural vegetation cover is grassy wooded and arboreal savanna (Cerrado) and the riparian forest is savanna with and without gallery forest and alluvial formations (trees, shrubs and herbs) (SILVA et al., 2011).
Because of the uniqueness of the local landscape, the municipality is located in a region classified as of extremely high importance for biodiversity conservation and has two conservation units: the Serra da Bodoquena National Park and the Cara da Onça State Private Natural Heritage Reserve (Reserva Particular do Patrimônio Natural - RPPN) (BRASIL, 2007).

\section{MATERIALS AND METHODS}

The risk mapping was performed by constructing a spatial database organized in the ArcGIS version 10.2 software based on a modified methodology of the procedures described in Silveira et al. (2008). Although the types and number of factors reported in the literature varied (PEZZOPANE et al., 2001; CHUVIECO et al., 2010; SOTO, 2012; POURTAGHI et al., 2015), we opted for the definitions of frequently used explanatory variables that are representative of the area and freely available. All variables considered in the risk analysis were normalized on a fuzzy scale, ranging from 0 to 1 , with values closer to 1 representing higher risk. The materials and the spatial analysis procedures used in each step of the mapping are described sequentially.

(1) Sun exposure aspect: this factor is important because the risk of fire is a function of the energy available for moisture reduction in combustible materials; therefore, aspects with a higher risk of fires are those with greater sun exposure (PEZZOPANE et al., 2001). This step involved drafting a slope orientation map using an SRTM (Shuttle Radar Topography Mission) image interpolated to 30 meters spatial resolution by Valeriano (2008). Then, a reclassification ranging from 1 to 4 was performed (from smallest to largest influence on fire hazard) in the following order: South, East, North and West. After reclassification, the linear increasing fuzzy function was applied.

(2) Terrain slope: this factor is important because higher slope values are associated with an increased risk of forest fires (PEZZOPANE et al., 2001). The slope map was drafted using the SRTM image (VALERIANO, 2008) and then classified into six classes, as proposed by Jaiswal et al. (2002), in the following order: a) 0 to $3 \%$; b) 3 to $5 \%$; c) 5 to $10 \%$; d) 10 to $15 \%$; e) 15 to $35 \%$; and f) $>35 \%$. After classification, a linear increasing fuzzy function was applied to the raster dataset.

Revista Árvore, Viçosa-MG, v.40, n.6, p.1003-1011, 2016

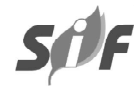


(3) Rainfall: this factor is important because a greater number of consecutive days without rain implies a greater climate risk of fire (ALVES; NÓBREGA, 2011). A relationship between the greatest water stress, caused mainly by drought and differences in rainfall distribution, and the highest incidence and extent of forest fires was established by Nelson (2001). In this study, the monthly rainfall averages for the five driest months of the year were considered because the risk of fire due to a lack of rainfall is a function of vegetation water stress. Rainfall data were compiled from eight meteorological stations on the Brazilian Agricultural Research Corporation (Empresa Brasileira de Pesquisa Agropecuária - EMBRAPA, 2014) website, collected by the National Water Agency (Agência Nacional de Águas - ANA). The dry season rainfall variability map (averages of the five driest months) was produced based on the inverse distance weighted (IDW) interpolation method. Then, the linear decreasing fuzzy function was applied. The driest locations were considered to have the highest risk of fire.

(4) Proximity to roads: the areas along highways have higher risk of forest fires because, according to Ferraz; Vettorazzi (1998) and Silva et al. (2004), they are areas subject to vehicle and cargo fires and fires produced by those who pass by the area. Therefore, areas closest to the road network are at a greater risk. A distance map was created based on road vectors from the Brazilian Institute of Geography and Statistics (Instituto Brasileiro de Geografia e Estatística - IBGE, 2013) on a scale of 1:250,000, adjusted to a $1: 100,000$ scale, from band 8 of the OLI sensor of the Landsat- 8 satellite in point orbit $226 / 74$ on 9/ $21 / 2014$, geometrically corrected (L1T Level). The OLI sensor data were obtained from the United States Geological Survey (USGS) (http://www.usgs.gov/). After calculating the Euclidean distance of roads (including pavements with and without asphalt pavement), a transformation of the distance using the linear decreasing fuzzy function was performed so that areas closer to roads have a greater risk of fire.

(5) Proximity to urban centers and rural settlements: the fragments near urban centers experience a constant threat of loss of area or even total elimination because of the misuse of these areas (GUTZWILLER; BARROW, 2003), in addition to threats similar to those for fragments near the road network (CHEN et al., 2001). Therefore, areas closest to urban areas have greater risk. Based on the urban polygon, visually photo-interpreted data from the same 8 band images used for determining the roads, a space analysis operation was conducted using the Euclidean distance method. Then, the linear decreasing fuzzy function was applied because the risk decreases as the distance from the urban area increases. The same fuzzy function was applied to the Euclidean distance of the rural settlement polygons (SISLA, 2007).

(6) Proximity to the hydrographic network: bodies of water are considered to be a barrier to the spread of fire (FORMAN; COLLINGE, 1997). Thus, the map of distances to bodies of water was normalized (fuzzy scale: 0 to 1 ) using a linear increasing function; consequently, the areas closest to bodies of water have the lowest values in this common scale. The cartographic base used for the drainage network was obtained by SISLA/IMASUL on a scale of $1: 100,000$.

(7) Vegetation use and cover: consultations with experts and the literature (FERRAZ; VETTORAZZI, 1998; PEZZOPANE et al., 2001; MISTRY; BERARDI, 2005) allowed an assessment of the influence of the different land uses and vegetation covers of the forest fragments on the risk of fires. The assessment was performed using the mapping of the land use and vegetation cover of the state of Mato Grosso do Sul conducted by Silva et al. (2011). The weights associated with the land uses and vegetation covers during the reclassification are shown in Table 1, which are adapted from Setzer; Sismanoglu (2012). After reclassification, a linear increasing function was applied to the weights.

(8) Hotspots: the expression "hotspots" is used to represent the heat signatures on the soil surface picked up by sensors in space. Thus, any object on the surface of the Earth with temperatures above $47^{\circ} \mathrm{C}$ is interpreted by remote sensors as being a hotspot (CHUVIECO; MARTÍN, 2004). Even if they are not necessarily burned areas, hotspots are a great resource for identifying areas with higher propensity for fires. In the hotspot monitoring website of the INPE (http:/ /www.dpi.inpe.br/proarco/bdqueimadas/) (2015), 1,726 points were detected from $1 / 6 / 1998$ to $3 / 17 / 2015$, which served as an input in the GIS for developing the heat density map using the Kernel statistical method (PARZEN, 1962). The hotspot density map was subjected to a linear increasing fuzzy function. A higher density of hotspots means a greater likelihood of fire. 
Table 1 - Risk weighting used for land use and vegetation cover.

Tabela 1 - Ponderação de risco utilizada para o uso e cobertura da terra.

\begin{tabular}{lc}
\hline \multicolumn{1}{c}{ Land use and vegetation cover } & Weight \\
\hline Water bodies. & 0 \\
\hline Fa - Riparian Vegetation: alluvial, herbaceous, shrubby, along rivers. & 1 \\
\hline Cs - Seasonal Deciduous Forest, Submontane (Forest, Dry Forest, Limestone Forest). & 2 \\
\hline Sd - Sava
\end{tabular}

Sd - Savanna (Cerrado), Forested (Cerradão).

Sas - Savanna (Cerrado), without gallery forest.

Saf - Savanna (Cerrado), with gallery forest.

$\mathrm{Sg}+\mathrm{Sa}$ - Savanna (Cerrado), Grassy-Woody + Arboreal.

$\mathrm{Sa}+\mathrm{Sg}$ - Savanna (Cerrado), Arboreal + Grassy-Woody.

$\mathrm{Sa}+\mathrm{Sd}$ - Savanna (Cerrado), Arboreal + Forested.

$\mathrm{Sd}+\mathrm{Sa}$ - Savanna (Cerrado), Forested + Arboreal.

Vs.Cs - Secondary Vegetation of Submontane Deciduous Seasonal Forest.

$\mathrm{SNc}-(\mathrm{Sd}+\mathrm{Cs})$ - Enclave, Savanna/Submontane Deciduous Seasonal Forest (Woods).

Vs.S - Secondary Savanna Vegetation.

Sgs - Savanna (Cerrado), without gallery forest.

Ap.Cs - Livestock (Planted pasture), Pasture planted in the Submontane Deciduous Seasonal Forest Region.

$\mathrm{Sd}+\mathrm{Sg} /$ - Savanna (Cerrado), Forested + Grassy-Woody.

$\mathrm{Td}+\mathrm{Ta}$ - Steppe savanna (Chaco), Forested + Arboreal.

Im - Degraded areas from mining.

Ap.Fa - Planted pasture in the Alluvial Semideciduous Forest Region.

Ac. S - Agriculture in the Savanna Region.

Ag_ar - Agriculture (rural settlements).

Ap.S - Pasture planted in the Savanna Region.

Iu - Urban Influence.

Source: Adapted from Silva et al. (2011) and Setzer; Sismanoglu (2012).

After preparing the eight fuzzy probability maps of the occurrence of a forest fire, a diffuse overlay method was used with the increasing SUM operator, which incorporates the idea that the combination of multiple instances of an occurrence is more important than any individual entry (ESRI, 2013).

\section{RESULTS}

The municipality of Bodoquena had a high risk of forest fire in the north-central region extending south toward the Serra da Bodoquena National Park, toward Cara da Onça State RPPN and along the highways that cross the municipality (Figure 2).

The hotspot occurrence density map revealed that the concentration of occurrences is located in the central and northern regions of the municipality, which is associated with the presence of roads and the occupation by rural settlements (Figure 3 ). The high densities of hotspots in the south of the municipality differ from those observed to the north because they are not associated with the roads but rather with the presence of rural settlements to the southwest, in an area in contact with the conservation units.

\section{DISCUSSION}

The spatial distribution of forest fire risk areas in the municipality of Bodoquena consistently reflected the effect of each explanatory variable of the model presented. The combined use of environmental variables traditionally used in studies of forest fire risk assessment in Brazil (FERRAZ; VETTORAZZI, 1998; PEZZOPANE et al., 2001; SILVEIRA et al., 2008; RIBEIRO et al., 2012) with the analysis of the influence of rural settlements and the density of hotspots detected in the municipality over the past 17 years was important for risk detection based on remote sensing data and spatial analysis techniques.

The forest fire risk and hotspot density maps present a concerning picture of threats to the Pantanal Biome, in the northeastern portion of the city, in the surroundings of the forest remnants of the Atlantic Forest (southwest of the municipality) and in the other areas of the municipality in the Cerrado domain. Such findings corroborate the predicted consequences of global and particularly regional climate change that forest fires will increase in the region (GFMC, 2007).

Revista Árvore, Viçosa-MG, v.40, n.6, p.1003-1011, 2016 


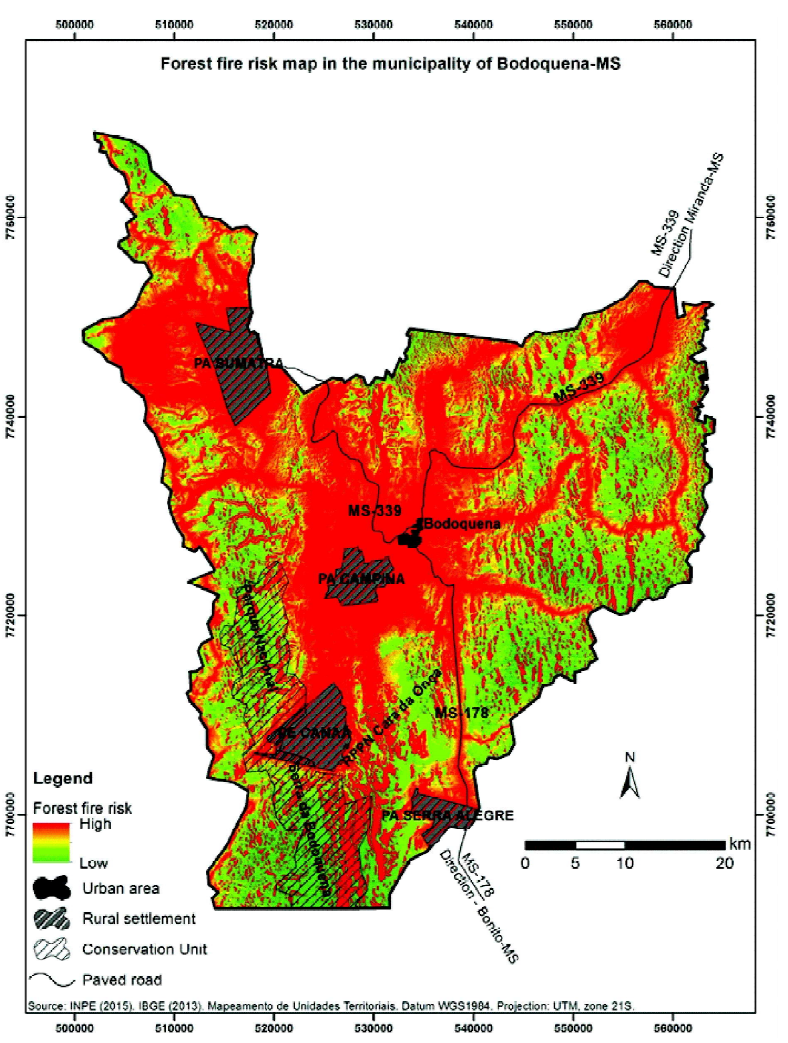

Figure 2 - Forest fire risk map in the municipality of BodoquenaMS.

Figura 2-Carta de risco de incêndio florestal no município de Bodoquena-MS.

We highlight the importance of specific actions of prevention and monitoring of burnings around the conservation units of the municipality, particularly in the Serra da Bodoquena National Park, which is bordered by areas with high risk of forest fires because of the natural and physical aspects, especially the presence of rural settlements. In addition to the irreversible damage to local biodiversity that may be caused by agricultural burnings, there is damage to local infrastructure (electricity transmission networks, roads, increased erosion, etc.), as well as damage to the health of the local population (SILVA, 2001), mainly in the rural settlements nearby. Forest fires in protected areas are widely reported in the literature, which reinforces and emphasizes the need for preventive actions to monitor and combat fires (SILVA et al., 2013; SILVEIRA et al., 2013; TEBALDI et al., 2013; OLIVEIRA; CRUZ, 2014; LEMES et al., 2014; SILVÉRIO NETO et al., 2015).

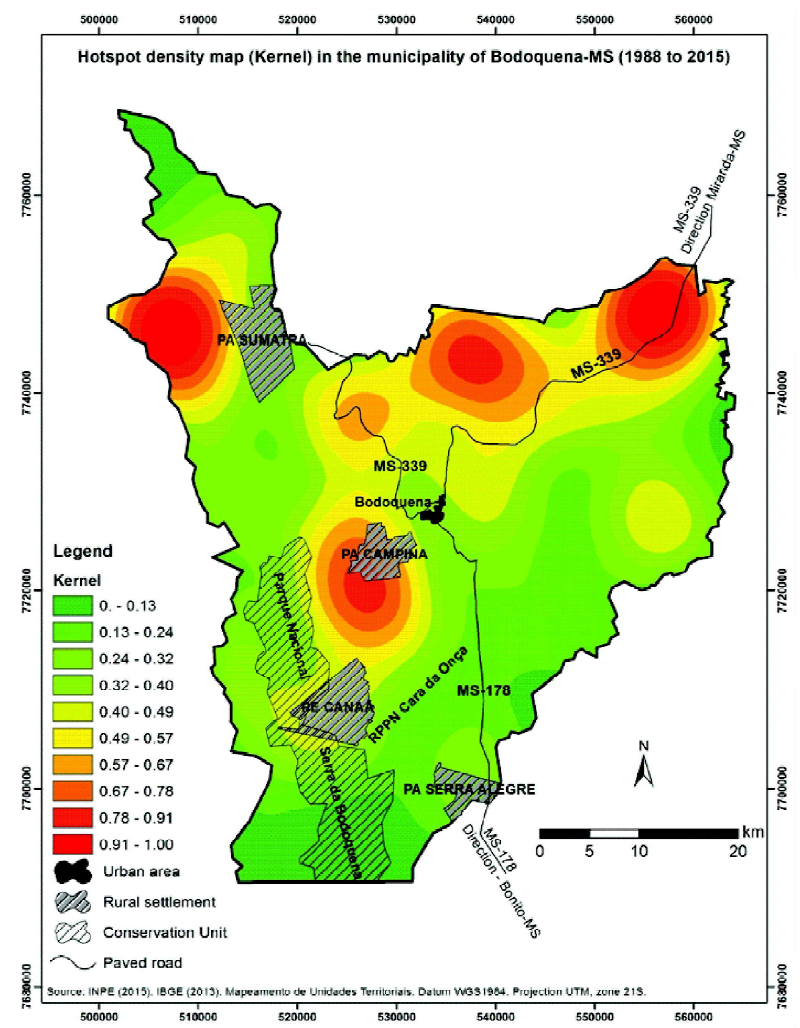

Figure 3 - Hotspot density map recorded in the municipality of Bodoquena, Mato Grosso do Sul, from 1/6/1998 to $3 / 17 / 2015$.

Figura 3 - Carta de densidade de focos de calor registrados no município de Bodoquena-MS durante o periodo de 06/01/1998 a 17/03/2015.

In general, all the combined factors resulted in the expression of areas with high risk and hotspots along the roads, except for the hotspots on highway MS-178 south of the municipality in the direction of Bodoquena-Bonito. This finding is related to environmental variables; however, it is believed that with the recent asphalt paving (CORREIO DO ESTADO, 2013), there will be an increased risk of fire, which will require special attention from the government, in partnership with private initiatives for preventive measures, based on the recommendations described by Ribeiro (2004).

\section{CONCLUSION}

The combined use of remote sensing data and spatial analysis techniques allowed the conclusion that the municipality of Bodoquena has a high risk 
of forest fires in areas of highly rich biodiversity, especially in the areas surrounding the Serra da Bodoquena National Park and the Mato Grosso do Sul Pantanal.

The margins of the rural settlement areas, urban areas and highways have a high risk of forest fires and a high density of hotspots, except for highway MS-178, which, being recently paved, revealed a low density of hotspots, but the risk of fire was mapped as high.

We stress the importance of carrying out further work to statistically assess the relationship among the hotspots, the fire risk map and the occurrences of fire recorded by the municipality. It is also recommended to create a municipal fire prevention, monitoring and control plan structured on a geographical database.

\section{REFERENCES}

ALMEIDA, F.F.M. Geologia da Serra da Bodoquena (Mato Grosso), Brasil. Boletim da Divisão de Geologia e Mineralogia, DNPM, v.219, p.1-96, 1965.

ALVES, K.M.A.S.; NÓBREGA, R.S. Uso de dados climáticos para análise espacial de risco de incêndio florestal. Mercator, v.10, n.22, p.209219,2011

BRASIL. Ministério das Minas e Energias. Secretaria Geral. Projeto RADAMBRASIL: Geologia, Geomorfologia, Pedologia, Vegetação e Uso potencial da terra. Folha SF.21 - Campo Grande. Rio de Janeiro: 1982.

BRASIL. Ministério do Meio Ambiente: Áreas prioritárias Conservação, Uso Sustentável e Repartição de benefícios da Biodiversidade Brasileira. Brasília: 2007.301p.

BRASIL. Plano de conservação da bacia do alto Paraguai: análise integrada e prognóstico da Bacia do Alto Paraguai. Brasília: PNMA, 1997. 369p.

BURROUGH, P.A. Fuzzy mathematical methods for soil survey and land evaluation. European Journal of Soil Science, v.40, n.3, p.477$492,1989$.

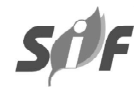

CHEN, K.; BLONG, R.; JACOBSON, C. MCERISK: Integrating multicriteria evaluation and GIS for risk decision-making in natural hazards. Environmental Modelling \& Software, v.16, n.4, p.387-397, 2001.

CHUVIECO, E.; MARTÍN, M.P. Nuevas Tecnologías para la estimación del riesgo de incendios forestales. Madrid: Consejo Superior de Investigaciones Científicas, 2004. 190p.

CHUVIECO, E.; AGUADO, I.; YEBRA, M.; NIETO, H.; SALAS, J.; MATÍN, M.P.; VILAR, L.; MARTÍNEZ, J.; MARTÍN, S.; IBARRA, P.; RIVA, J.; BAEZA, J.; RODRÍGUEZ, F.; MOLINA, J.R.; HERRERA, M.A.; ZAMORA, R. Development of a framework for fire risk assessment using remote sensing and geographic information system technologies. Ecological Modelling, v.221, n. 1, p.46-58, 2010.

CORREIO DO ESTADO. Pavimentação de rodovia turística Bonito-Bodoquena será entregue. Campo Grande, 17 de fev. de 2013.

COMPANHIA DE PESQUISA DE RECURSOS MINERAIS - CPRM. Serviço Geológico do Brasil. 2006 [acesso em 10 mar. de 2013]. Disponível em: www.geobank.sa.cprm.gov.br

EMPRESA BRASILEIRA DE PESQUISA AGROPECUÁRIA - EMBRAPA. Estações pluviométricas. [acessado em 15 de jan. de 2014]. Disponível em: http://www.cpao.embrapa.br/ clima/clima.cpao/index.php?pg=chuvams.

EMPRESA BRASILEIRA DE PESQUISA AGROPECUÁRIA - EMBRAPA. Sistema Brasileiro de Classificação de Solos. 3 ed. - Brasília, DF: 2013. 353p.

ESRI. ArcGIS/ArcInfo 10.2 (Computer Software).New York: 2013.

FERRAZ, S.F.B.; VETTORAZZI, C.A. Mapeamento de risco de incêndio florestal por meio de sistema de informações geográficas (SIG). Scientia Florestalis. n.53, p.39-48, 1998.

FORMAN, R.T.T.; COLLINGE, S.K. Nature conserved in changing landscapes with and without spatial planning. Landscape and Urban Planning, v.37, n.1-2, p.129-135, 1997.

Revista Árvore, Viçosa-MG, v.40, n.6, p.1003-1011, 2016 
GFMC. REGIONAL SOUTH AMERICA WILDLAND FIRE NETWORK. [accessed on: 22 Set. 2014]. Available at: http:// www.fire.unifreiburg.de/GlobalNetworks/ SouthAmerica/SouthAmerica.html.

GUTZWILLER, K.J.; BARROW JR., W.C. Influences of roads and development on bird communities in protected Chihuahuan Desert landscapes. Biological Conservation, v.113, n.2, p.225-237, 2003.

INSTITUTO BRASILEIRO DE GEOGRAFIA E ESTATÍSTICA - IBGE. Malha territorial digital. 2013. [acessado em: 15 de março de 2015] Disponível em: http://dados.gov.br/dataset/ malha-geometrica-dos-municipios-brasileiros.

\section{INSTITUTO BRASILEIRO DE GEOGRAFIA E} ESTATÍSTICA - IBGE. 2015. [acessado em: 09 de março de 2015]. Disponível em: http:// www.cidades.ibge.gov.br/xtras/ perfil.php?lang $=\&$ codmun $=500215 \&$ search $=$ matogrosso-do-sul|bodoquena

\section{INSTITUTO BRASILEIRO DE GEOGRAFIA E} EStATÍSTICA - IBGE. Mapa de Biomas do Brasil. 2004. [acessado em: 19 de mar. 2015]. Disponível em:<http://www.ibge.gov.br/home/ presidencia/noticias/21052004biomashtml.shtm>

\section{INSTITUTO NACIONAL DE PESQUISAS} ESPACIAIS - INPE. BDQUEIMADAS Banco de Dados Queimadas. [acessado em 17 de mar. de 2015] Disponível em: http:// www.dpi.inpe.br/proarco/bdqueimadas

JAISWAL, R.K.; MUKHERJEE, S.; RAJU, K.D.; SAXENA, R. Forest fire risk zone mapping from satellite imagery and GIS. International Journal of Applied Earth Observation and Geoinformation, v.4, n.1, p.1-10, 2002.

LEMES, G.P.; MATRICARDI, E.A.T.; COSTA, O.B.; LEAL, F.A. Avaliação espaço-temporal dos incêndios florestais no Parque Nacional Serra da Canastra no período de 1991 a 2011.

Ambiência, v.10, p.247-266, 2014.

(Suplemento).

MISTRY, J.; BERARDI, A. Assessing fire potential in a Brazilian Savanna nature reserve. Biotropica, v. 37, n. 3, p.439-451, 2005.
MATO GROSSO DO SUL (Estado). Atlas

Multirreferencial. Campo Grande: Secretaria de Planejamento e Coordenação Geral (SEPLAN), 1990. Escala 1:1.500.000.

NELSON, B.W. Fogo em florestas da Amazônia Central em 1997. In: SIMPÓSIO BRASILEIRO DE SENSORIAMENTO REMOTO, 10, , 2001, Foz do Iguaçu. Anais... Foz do Iguaçu: INPE 2001. p.1675-1682.

OLIVEIRA, L.S.; CRUZ, M.L.B. Vetores de pressão sobre a Unidade de Conservação de proteção integral: A Estação Ecológica de Aiuaba, Ceará, Brasil. Revista Brasileira de Geografia Física, v.7, n.6, p.1126-1132, 2014.

PARZEN, E. On estimation of a probability density function and mode. The Annals of Mathematical Statistics, v.33, n.3, p.10651076, 1962.

PEZZOPANE, J.E.M.; OLIVEIRA NETO, S.N.; VILELA, M.F. Risco de incêndios em função da característica do clima, relevo e cobertura do solo. Floresta e Ambiente, v.8, n.1, p.161-166, 2001.

POURTAGHI, Z.S.; POURGHASEMI, H.R.; ROSSI, $M$. Forest fire susceptibility mapping in the Minudasht forests, Golestan province, Iran. Environmental Earth Sciences, v.73, n.4, p.1515-1533, 2015.

RAMOS, V.S.; DURIGAN, G.; FRANCO, G.A.D.C.; SIQUEIRA, M.F.; RODRIGUES, R.R. Árvores da Floresta Estacional Semidecidual: guia de identificação de espécies. São Paulo: USP, 2008. 320p.

RIBEIRO, G.A. Estratégias de prevenção contra os incêndios florestais. Floresta, v.34, n.2, p.243$247,2004$.

RIBEIRO, L.; KOPROSKI, L.P.; STOLLE, L.; LINGNAU, C.; SOARES, R.V.; BATISTA, A.C. Zoneamento de riscos de incêndios florestais para a fazenda experimental do Canguiri, Pinhais (PR). Floresta, v.38, n.3, p.561-572, 2008.

RIBEIRO, L.; SOARES, R.V.; BEPLLER, M. Mapeamento do risco de incêndios florestais no 
município de Novo Mundo, Mato Grosso, Brasil. Cerne, v.18, n.1, p.117-126, 2012.

SAlZO, I. (Coord.). Plano de Manejo do Parque Nacional da Serra da

Bodoquena. ICMBio. Brasília: Instituto Chico Mendes de Conservação da Biodiversidade, 2013.

SETZER, A.W.; SISMANOGLU, R.A. Risco de fogo: metodologia do cálculo - descrição sucinta da versão 9. INPE, 2012. [acessado em: 15 de set. de 2014]. Disponível em: http://

queimadas.cptec.inpe.br/ rqueimadas/documentos/ RiscoFogo_Sucinto.pdf

SILVA, A.C.C.; PRATA, A.P.N.; SOUTO, L.S.; MELLO, A.A. Aspectos de ecologia de paisagem e ameaças à biodiversidade em uma unidade de conservação na Caatinga, em Sergipe. Revista Árvore, v.37, n.3, p.479-490, 2013.

SILVA, J.C.; FIEDLER, N.C.; RIBEIRO, G.A.; SILVA JÚNIOR, M.C. Avaliação de brigadas de incêndios florestais em unidades de conservação. Revista Árvore, v.27, n.1, p.95-101, 2003.

SILVA, J.S.V.; POTT, A.; ABDON, M.M.; POTT, V.J.; SANTOS, K.R. Projeto GeoMS:

Cobertura vegetal e uso da terra do Estado de Mato Grosso do Sul. Campinas: Embrapa Informática Agropecuária, 2011.

SILVA, J.C. Diagnóstico das áreas de maior incidência de incêndios

florestais em Unidades de Conservação Pertencentes à APA Gama - Cabeça de Veado. 2001. 59 f. (Dissertação em Ciências Florestais) -

Universidade de Brasília, Brasília, 2001.

SILVA, S.A.; CABRAL, J.B.P.; SCOPEL, I. Incêndios em vegetação entre 2000 e 2002, nas propriedades rurais limítrofes às rodovias pavimentadas do município de Jataí-GO. Jataí. Geoambiente On-line, n.2, p.1-20, 2004.
SILVEIRA, A.H.M.; QUEIROZ, A.F.S.; SILVA, B.C.O.; SILVA, F.M.; COSTA JUNIOR, N.P. Proposta Metodológica para Risco de Incêndio Florestal: Estudo de Caso na Zona de Proteção Ambiental (ZPA-1) em Natal/RN. Revista Brasileira de Geografia Física, v.6, n.5, p.1174-1192, 2013.

SILVEIRA, H.L.F.; VETTORAZZI, C.A.; VALENTE, R.O.A. Avaliação multicriterial no mapeamento de risco de incêndios florestais, em ambiente SIG, na bacia do Rio Corumbataí, SP. Revista Árvore, v.32, n.2, p.259-268, 2008.

SILVÉRIO NETO, R.; BENTO, M.C.; MENEZES, S.J.M.C.; ALMEIDA, F.S. Caracterização da cobertura florestal de Unidades de Conservação da Mata Atlântica. Floresta e Ambiente, v.22, n.1, p.32-41, 2015.

\section{SISTEMA INTERATIVO DE SUPORTE AO LICENCIAMENTO AMBIENTAL - SISLA. 2007.} [acessado em: 5 de abr. de 2014]. Disponível em: http://sisla.imasul.ms.gov.br/sisla/.

SOTO, M.E.C. The identification and assessment of areas at risk of forest fire using fuzzy methodology. Applied Geography, v.35, n.12, p.199-207, 2012.

TEBALDI, A.L.C.; FIEDLER, N.C., JUVANHOL, R.S.; DIAS, H.M. Ações de prevenção e combate aos incêndios florestais nas Unidades de Conservação Estaduais do Espírito Santo. Floresta e Ambiente, v.20, n.4, p.538-549, 2013.

VALERIANO, M.M. TOPODATA: guia de utilização de dados geomorfométricos locais. São Jose dos Campos: INPE, 2008. 44p.

VETTORAZZI, C.A.; FERRAZ, S.F.B. Uso de sistemas de informações geográficas aplicados à prevenção e combate a incêndios em fragmentos florestais. Série Técnica IPEF, v.12, n.32, p.111-115, 1998. 